\title{
PESANTREN AND PARTICIPATORY DEVELOPMENT The Case of the Pesantren Maslakul Huda of Kajen, Pati, Central Java
}

\author{
Bambang Budiwiranto \\ The University of Queensland, Australia
}

\begin{abstract}
This chapter discusses the implementation of participatory development in the pesantren Maslakul Huda of Kajen, Pati, Central Java. It argues that participatory development in the pesantren Maslakul Huda has led to the creation of genuine participation in which local people are able to identify their own problems and potentials, and to create alternative solutions. The role of the kyai in this pesantren is limited to giving Islamic justification to the acceptance of participatory development, and program implementation is in the hands of senior santris and village facilitators. The use of participatory action research and the creation of the self-help group as a people's forum enable them to express their own perspective on their problems without the kyai's interference. However, the pesantren utilises participatory development to enhance its economic position among the local people.
\end{abstract}

Key words: Pesantren, participatory development, kyai, social service.

\section{Introduction}

Since the late 1970s non-government organisations in Indonesia, including LP3ES (Lembaga Penelitian, Pendidikan, dan Penerangan Ekonomi dan Sosial, The Indonesian Institute for Social and Economic Research, Education and Information), have promoted participatory development strategies in their activities. Such organisations have sought to redress the failure of top-down modernisation of the New Order government as a strategy to bring about equality in economic prosperity. Despite the fact that Indonesia's economy grew at 8.0 
percent annually in the period of $1965-1980^{1}$ and at 5.1 percent during $1980-1988,{ }^{2}$ the New Order modernisation denied equality in sharing the process and product of development and denied politically meaningful participation in development. ${ }^{3}$

LP3ES used the pesantren as an entry point to promote a participatory approach to social and economic development. It believed that pesantren would be able to facilitate participatory development. Furthermore, it recognised that the significant role of pesantren within rural society extended beyond provision of religious and social services. The pesantren's capacity to stimulate social mobilisation in pursuit of other purposes was seen as an important asset to the implementation of participatory development.

The pesantren itself delivers religious sermons and lectures to its community in forums for children and adults. ${ }^{4}$ It also gathers zakat (compulsory alms tax) from wealthy people and redistributes it to the impoverished. ${ }^{5}$ The pesantren provides security for society in times of societal and personal crisis by organizing people in thripath (Sufi orders). ${ }^{6}$ It was under such thripath organisation that the pesantren mobilised a peasant protest movement to attack the Dutch colonists in West Java in $1883 .{ }^{7}$

${ }^{1}$ World Bank, World Development Report 1991: Poverty (Oxford: Oxford University Press, 1991), p. 180.

2 Arief Budiman, "The Emergence of the Bureaucratic Capitalist State in Indonesia," in Tech Ghee Lim (ed.), Reflections on Development in Southeast Asia (Singapore: Institute of Southeast Asian Studies, 1988), p. 127.

3 Purwo Santoso, "Political Challenges to Sustainable Development in Indonesia," (Unpublished MA Thesis, Ann Arbour, 1992), pp. 121-137.

4 M. Dawam Rahardjo, "The Kyai, the Pesantren and the Village: A Preliminary Sketch," Prisma: The Indonesian Indicator, vol. 1, no. 1 (1975): pp. 32-43.

5 Mansour Fakih, "Pengembangan Masyarakat di Pesantren: Hambatan dan Permasalahan," in Manfred Oepen and Wolfgang Karcher (eds), The Impact of Pesantren in Education and Community Development in Indonesia (Jakarta: P3M, 1985), pp. 148-160.

${ }^{6}$ Sidney Jones, "The Javanese Pesantren: Between Elite and Peasantry," in Reshaping Local Worlds: Formal Education and Cultural Change in Rural South East Asia (New Haven, Conn: Yale Centre for International and Area Studies, 1996), pp. 19-41; Rahardjo, "The Kyai, the Pesantren and the Village."

7 Martin van Bruinessen, Kitab Kuning,Pesantren dan Tarikat: Tradisi-Tradisi Islam di Indonesia (Bandung: Mizan, 1995); Sartono Kartodirdjo, Protest Movement in Rural Java: A Study of Agrarian Unrest in the Nineteenth and Early Twentieth Centuries. Singapore: Oxford University Press, 1973). 
The paradigm of participatory development, however, is inconsistent with pesantren characteristics. The pesantren life is strongly characterised by hierarchical and patron-client relationships in which the kyai (pesantren religious scholar) represents a charismatic leader highly respected not only by santris (pesantren students), but also by the surrounding society. This charismatic leadership encourages the people to obey the kyai's order, and to avoid disappointing and opposing him, as these actions may impede barakah (blessing) and may even attract kuwalat (curse). Furthermore, despite the pesantren's significant social role within society, the services it conducts are intended to preserve its domination over society and to enhance the kyai's social position. ${ }^{8}$

In contrast, participatory development advocates self-reliance, selfdetermination and democratisation, ${ }^{9}$ and requires the pesantren to relinquish to society the right to make decisions that affect people's lives. ${ }^{10}$ In other words, the principles of participatory development require that the pesantren only act as a facilitator: it establishes the circumstances that enable the people to identify their own needs, to formulate their own purposes, to become the main executor of development, and to evaluate and share its results. This markedly differs from the paradigm underlying the pesantren's provision of social services to the society, that is, charity as a moral obligation from patron (the pesantren) to clients (society). In this context, as the pesantren seeks to preserve its hierarchical solidarity and influence within its society, the adoption of LP3ES to participatory development could become counter-productive. Such a contradiction raises the question of the capacity of the pesantren to conduct effective participatory development.

This paper examines the implementation of participatory development in the pesantren Maslakul Huda of Kajen, Pati, Central Java, between 1977 and 1993. It focuses on three important issues: To what extent is the pesantren an effective vehicle to implement participatory development in rural society? Does participatory

\footnotetext{
8 Hiroko Horikoshi, "A Traditional Leader in a Time of Change," (Unpublished Ph.D Thesis, Urbana: University of Illinois at Urbana-Champaign, 1976); Iik Arifin Mansurnoor, Islam in an Indonesian World: Ulama of Madura (Yogyakarta: Gadjah Mada University Press, 1990).

${ }^{9}$ Fakih, "Pengembangan Masyarakat di Pesantren."

${ }^{10}$ M Nashihin Hasan, "Karakter dan Fungsi Pesantren," in Oepen and Karcher (eds), The Impact of Pesantren in Education, pp. 108-109.
} 
development change the pesantren domination in its surrounding society? To what extent does the participatory development paradigm introduced by LP3ES in the pesantren stimulate people participation?

This study argues that the effectiveness of the pesantren to stimulate people participation in development cannot be explained solely by formulaic participatory development procedures, but rather it should be considered in the specific cultural contexts where the pesantren exists. Despite the fact that participatory development in the pesantren creates people participation with different procedures and at different levels, participatory development does not change the pesantren's domination over their surrounding society.

\section{A Brief Description}

\section{of Kajen Village and the Pesantren Maslakul Huda}

The village of Kajen, one of 22 villages in Margoyoso sub-district, is situated around $18 \mathrm{~km}$ north of Pati, Central Java. It extends over 63.460 hectares and has around 3,292 inhabitants. Unlike surrounding villages, Kajen does not have wet field cultivation (sawah), ${ }^{11}$ which has led the villagers to pursue non-agricultural livelihoods such as trades and transportation services. Villagers working as farmhands and manual labourers in factories must work outside Kajen. Some of the villagers work in providing for the everyday and educational needs of santri, such as food and study equipment. To work as farmers, the villagers must rent farmland in surrounding villages. Burger ${ }^{12}$ noted that the rental of farmland is commonplace for Kajen villagers. The richer villagers even purchase some farmlands as rental properties in neighbouring villages. The development of the tapioca industry in the neighbouring village of Ngemplak Kidul in the 1970s, however, led some villagers to estlablish tapioca crisp (kerupuk) home-industry. The product of this home-industry is sold both in local markets and to brokers who resell it outside Kajen.

11 Arief Mudatsir, "Kajen Desa Pesantren," in M. Dawam Rahardjo (ed.), Pergulatan Dunia Pesantren: Membangun dari Bawah (Jakarta: P3M, 1985), p. 197.

12 As quoted in Pradjarta Dirdjosanjoto, Memelihara Umat: Kiai Pesantren and Kiai Langgar (Yogyakarta: LKiS, 1999), p. 87. 
Since the end of the $17^{\text {th }}$ century Kajen ${ }^{13}$ has been associated with the story of Shaykh Ahmad Mutamakkin, the founder of the village. He became a saint who had an important role in the development of Islam in this village and surrounding cities of the north coast of Java. ${ }^{14}$ He is said to be buried in a grave next to his mosque, situated in the west side of the village. This grave is highly respected by local people and almost every day there are visitors who come to seek barakah, or to offer prayers to God. In commemorating Mutamakkin, the villagers hold hault5 for him, the annual event on the $10^{\text {th }}$ day of Muhłrram or Shura the first Islamic month). This lasts for seven days and nights, and attracts thousands of visitors from different villages and cities on the north coast of Java. These visitors to Mutamakkin's grave and haul

${ }^{13}$ As perdikan village, Kajen was not imposed with the obligation of paying tax to the government from the Dutch colonial period to 1958. In return, villagers were asked to maintain the mosque and the grave located in the village. They were also required to send four people to the district office for night watch, and provide eight people to carry water to the district head's (bupati) house. Furthermore, as perdikan village, the succession of the village head was not determined by village election but by inheritance, which had lasted until 1958. See, Dirdjosanjoto, Memelihara Umat, pp. 6667; Ahmad Syafi'i Mufid, Tangklukan, Abangan dan Tarekat: Kebangkitan Agama di Jawa (Jakarta: Yayasan Obor Indonesia, 2006), pp. 93-94. Unlike other villages, which have tanab bengkok. (village agricultural land given to the village head), in Kajen the village head does not get tanab bengkok, due to the lack of sawah. As a result, village revenue is very limited. Only once a year, the village gets additional income from tax of trading, art performances, and other related activities during the haul of Mutamakkin celebration. Although there was a monthly salary for village administrators, it was insufficient to meet daily expenses.

14 The story of Mutamakkin is alive among the villagers. It was written in classical Javanese literature entitled Serat Cebolek. See, Kuntowijoyo, Paradigma Islam: Interpretasi untuk. Aksi (Bandung: Mizan, 1991). Mutamakkin who lived in the mid $18^{\text {th }}$ century when the Mataram kingdom of Yogyakarta ruled the village was also a great ulama who was an expert in Islamic jurisprudence. His followers called him a saint (waliyullab).

15 Haul basically means the celebration to commemorate the day of someone's death. For respected people such as kyai and wali (saint), the celebration is conducted vigorously, and is characterised by the reading of doa (prayers), kbataman (reciting a whole chapter of the Qur'an), and conveying religious sermons. The visitors believe that reading special chanting at Mutamaikin's grave can attract baraka (blessing), and ensure their prayers to God are answered. This belief is influenced by the teachings of tasawnuf (Islamic mysticism) that are embraced by the local people. To hold the haul, a village committee is formed to collect funds (cash, or foods) from the villagers. This is not a difficult activity, as the villagers believe that their contribution to such events will attract baraka and also symbolise the relationship between them and Mutamakkin. See, Dirdjosanjoto, Memelihara Umat, pp. 88- 89. 
create economic opportunities for the villagers. Santris who have graduated from the pesantren also utilise the haul as an opportunity for reunion with fellow students, and to visit their kyai, in order to exchange information and to strengthen the teacher-disciple relationship.

In Kajen, the kyais, ${ }^{16}$ together with village administrators and wealthy people, are considered as wong gedhe (respected people), in contrast to wong awam (ordinary people). Even though the kyai is considered to be the most influential informal leader, the degree of their authority is determined by the strength of their relationship with Mutamakkin. ${ }^{17}$ The kyais who have the closest relationship with Mutamakkin are at the top of the wong gedhe layer, and are respected by other kyais, wealthy people and bureaucrats. This phenomenon is inseparable from the influence of thriqath teachings embraced by Kajen villagers, who believe in the karamah of Mutamakkin. For the thriqah followers, Mutamakkin is perceived as still being alive in another world even though he has died in this world. Therefore, in solving the problems of life, they always come to Mutamakkin's grave and ask for barakah. For example, a young educated kyai in Kajen whose son suffered from a severe illness which required surgery, visited Mutamakkin's grave to request barakah from him for his son.

Kajen is also known as desa pesantren (pesantren village) because there are fourteen pesantren ${ }^{18}$ in the village. Apart from the pesantren, Kajen also has other Islamic educational institutions: five Madrasah Aliyah (Senior High School), five Madrasah Tsanawiyah (Secondary School),

16 One of villagers said that "the kyai has spiritual force and Islamic knowledge exceeding ordinary people. Mastering religious knowledge is not an easy matter. Many people become mad due to their inability to digest it. A kyai, he must be an extraordinary person because no single kyai is mad. He must have spiritual force above other people." See, Dirdjosanjoto, Memelihara Umat, pp. 155-156.

17 Among kyai of Kajen there is a kinship system based on the descendants (Bani), namely Bani Salam, Bani Nawawi, and Bani Sirat. Each member of Bani is obliged to preserve his family identity, to maintain good relationships, and to help other members in all situations. These obligations are especially strong in respect to continuing their grandfather's mission to maintain and to develop Islamic values and education. See, Mufid, Tangklukan, Abangan dan Tarekat, p. 113.

18 These pesantren are Kulon Banon (TPII), Taman Pendidikan Tamrinul Huda (TPTH), Mathali'ul Huda, Maslakul Huda, Pesantren Putri Al-Badi'iyah, Pesarean, Kauman Kretek, Asrama Pelajar Islam Kajen (APIK), Permata, Raudhatul Ulum, Manbaul Ulum, Pesantren Putri Al-Inayah, Buludono and Polgarut Selatan. 
six Madrasah Ibtidaiyah (Primary School), and two kindergartens. These educational institutions accommodate around 2345 male and female santri and employ 120 teachers, 22 of whom are kyais. ${ }^{19}$ The large number of pesantren can be attributed to three important factors. First, like other kyais in Java, the kyais in Kajen (i.e. the Mutamakkin family) pay great attention to their children's Islamic education so that they can assume pesantren leadership after their fathers. All the kyais in Kajen claim descent from Mutamakkin. KH Sahal Mahfudh, the pesantren Maslakul Huda leader, is of the youngest or eighth generation. The second factor is that a newly established pesantren is regarded as the embodiment of the amarah (important message) of the kyai to his santri to continue the tradition of knowledge transmission. By observing this, the existence of the pesantren will always be maintained; therefore, if an old pesantren collapses, a new one will replace it. The third and final factor influencing the increase of pesantren in Kajen is a pesantren regulation requiring santri who come from places five kilometres outside the complex to live in dormitories, either inside or outside the pesantren. The increasing number of santri living outside has led to the transformation of their dormitories into new pesantren. ${ }^{20}$

The pesantren Maslakul Huda was established by KH Abdussalam and his son KH Mahfudz in 1910. This pesantren initially focused on kitab kuning. Two years later, $\mathrm{KH}$ Abdussalam and his brother $\mathrm{KH}$ Nawawi established Madrasah Mathali'ul Falah (PIM, Perguruan Islam Mathali'ul Falab) ${ }^{21}$ in the classical (madrasi) system. The establishment of the madrasab addressed their concerns about the inadequacies of the pesantren educational system, which only relied on bandongan and sorogan systems. Like other pesantren such as Tebu Ireng of Jombang, this change was influenced both by KH Abdussalam's educational experience with the madrasi system in Mecca and Medina, and by the kyais response to Dutch colonials introducing a modern educational system.

19 Mudatsir, "Kajen Desa Pesantren,” p. 197.

20 Ibid., pp. 204-205

21 The name of PIM was proposed by KH Mahfudh Salam in 1922. 
Figure 1: Genealogy of Kyai Kajen

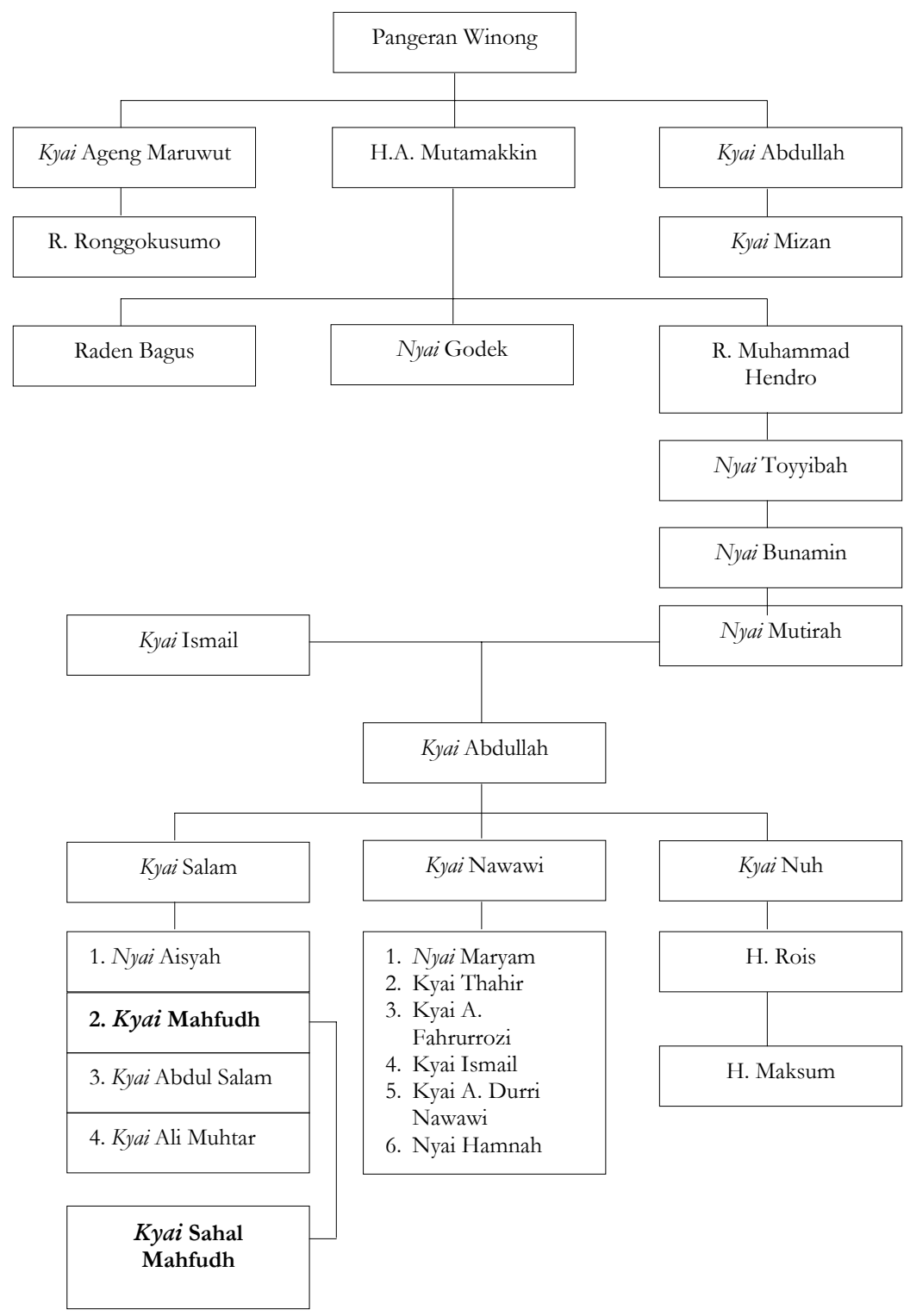

Source: Mufid, Tangklukan, Abangan dan Tarekat, p. 89. 
In 1951, the madrasab equipped its santri with non-religious subjects, such as English, Indonesian and Sociology, in compliance with a regulation issued by Ministry of Religious Affairs. ${ }^{22}$ However, when the government offered the graduates of this madrasab the 'state educational certificate' based on a national exam, it declined. The madrasah felt that acceptance of such an offer led to dependency of educational institutions on the state and resulted in the loss of the madrasab's control over determining the best curriculum for its santri. ${ }^{23}$

Under the leadership of KH Sahal Mahfudz since 1963, the pesantren Maslakul Huda has changed gradually. In 1976, the kyai's wife established the female pesantren Al-Badi'iyah to expand educational opportunities for female santri. ${ }^{24}$ In 1979, the pesantren established BPPM (Bureau of Community and Pesantren Development) to institutionalise the expansion of its role in social services. It also established BUMP (pesantren owned-enterprise bodies) such as banks and co-operatives in the 1990s. All of the above institutions are coordinated under Nurussalam Foundation with KH Sahal Mahfudh as the leader. The establishment of the foundation signified the changing of the kyai's leadership in the pesantren Maslakul Huda from sole leader to part of a collective leadership. Every institution under the foundation has the delegated authority to manage itself, including financial matters, and report its institutional development to the kyai. The santri also have the right to manage their own activities and to choose their leaders through presidium elections, in which three santri are elected and proposed to the kyai for approval. This process is different from that of other traditional pesantren, in which the santri leader is appointed by the kyai.

\section{Participatory Development and the Pesantren's Social Service}

The pesantren Maslakul Huda used religious justification to effectively enhance its social role through participatory development. In addition to religious service, the pesantren is morally obliged to offer social services to its surrounding society. The integration of

\footnotetext{
${ }^{22}$ Mahmud Yunus, Sejarab Pendidikan Islam di Indonesia (Yakarta: Mutiara, 1979); Faiqoh, Nyai: Agen Perubahan di Pesantren (Jakarta: Kucica, 2003), pp. 182-187.

${ }^{23}$ Despite this rejection, many PIM graduates have enrolled at leading universities such UGM (Gadjah Mada University) of Yogyakarta.

24 Alfoe Ni'am Alwie, Pesantren Maslakul Huda: Membentuk Insan Mandiri (Yogyakarta: Wisma KMF Papringan, 2004), pp. 20-21.
} 
participatory development into the pesantren's life represents one of the ways in which the pesantren fulfils this need. According to Sahal Mahfudh, the poor social and economic situation of villagers around the pesantren is of great concern. Most of the villagers do not have agricultural land or sufficient income to fulfil daily needs. In the past, his father $\mathrm{KH}$ Mahfudh Salam always offered charity to them, both sporadically and at times of special need, such as towards the end of the fasting month. However, there was concern that this tradition could lead to people's dependency on donations. Sahal Mahfudh accordingly developed an interest in enhancing the pesantren's role from mere religious institution to social service provider. $^{25}$

On one hand, participatory development creates opportunities for the pesantren to get involved in social services in a more organised way. On the other hand, it advocates democratisation, and tends to reduce the pesantren's domination over its community. Participatory development is metaphorically regarded as a big stream entering the pesantren life. Sahal Mahfudh applied the strategy of canalisation (kanalisasi) in adopting participatory development. The pesantren has the ability to direct changes to suit its own purposes by distributing this 'stream' into canals. The pesantren can also direct new streams into the canals to help achieve its own purposes, such as enhancing its role in social activity. While the pesantren conducts participatory development, it does not relinquish its domination within the society.

Mahfudh justified participatory development as social iba ${ }^{26}$ (worship), whose advantages extend not only to the individuals directing it, but also to the public. Furthermore, Mahfudh believed that adoption of participatory development fulfilled one of a Muslim leader's obligations towards his followers. He quoted the prophet tradition, stating that "anyone who does not take care of Islamic community affairs is not of my followers (ummah)". ${ }^{27}$ He also quoted

25 In the early 1970s, Mahfudh discussed this idea with Abdurrahman Wahid and shortly after that meeting, Wahid, who joined LP3ES, invited Mahfudh to send his santri to attend the LTPM training held in the Pesantren Pabelan in 1978.

${ }^{26}$ In this context, ibach is understood not in terms of performing prayers but of every good activity conducted for the sake of God that is also useful for human beings. This is similar to the concept of da wah bi al-holsproposed by Kyai A Basith from the pesantren Annuqayah.

${ }^{27}$ MA Sahal Mahfudh, Nuansa Fikih Sosial (Yogyakarta: LkiS, 1994), p. 362. 
'Umar bin al-Khat the Prophet Khalifors (successor), to stress the importance of paying attention to the poor. Al-Khat wrote "You should beware, do not stay distant from your community, approach the poorest people among them and give them opportunities to convey their opinion....". ${ }^{28}$ Mahfudh's argument reveals not only his role as cultural broker, as defined by Geertz, ${ }^{29}$ but also his creativity in making adjustments and innovations to assist his followers in understanding and accepting new social changes. ${ }^{30}$ This phenomenon is deeply rooted in pesantren tradition which was based on the Islamic

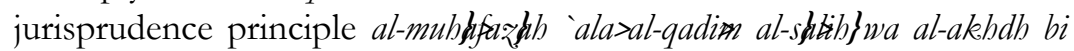
al-jadi $\gg$ al-aslah f $^{2}$ maintaining good old values and adopting better new values). This principle represented a survival mechanism for the pesantren - they could promote social changes without uprooting traditional values. In this context, the use of the Islamic injunction to justify participatory development, such as at the pesantren Annuqayah of Madura, is understandable.

Bearing in mind that there are fourteen pesantren in Kajen, the task of building the same world-view among them is considered essential to sustaining participatory development. As well as using Islamic justification, Sahal Mahfudh took advantage of the authority of the most respected kyai in Kajen, KH Abdullah Salam (sixth generation descendant of Mutamakkin), to support his efforts in disseminating participatory development. The support from this thripath leader enabled Sahal Mahfudh to convince other pesantren leaders to accept the new program. Most of the kyais in Kajen were suspicious of participatory development because they had bad memories of an initiative introduced before LP3ES launched the current program. Between 1972 and 1976, the Minister of Religious Affairs, Mukti Ali, oversaw a vocational skills development program for the santri. This program focused on vocational training, such as animal husbandry, printing, tailoring and crafting, and was intended to equip the santri with useful skills for building enterprise after graduating from the pesantren. However, many kyais considered such training to be a distraction from educational activity in the pesantren. They argued that

\footnotetext{
28 Ibid.

${ }^{29}$ Clifford Geertz, "The Javanese Kijaji: The Changing Role of A Cultural Broker," Comparative Studies in Society and History, 2: 2 (1960), pp. 228-249.

30 Horikoshi, "A Traditional Leader in a Time of Change."
} 
such programs changed the pesantren's mission, from institutions for tafaqquh fi $>$ al-di>to centres of animal husbandry and technical skillsnew foci which drew the santri's attention away from educational activities. Therefore, this program was not well developed, and was ultimately rejected by many kyais in Kajen and other areas. ${ }^{31}$

Like the pesantren Annuqayah, Maslakul Huda integrated participatory development into its structure by establishing BPPM PMH (Bureau of Society and Pesantren Development of the pesantren Maslakul Huda) in 1979.32 The establishment of BPPM demonstrates that the role of the pesantren is not merely to provide the surrounding society with religious knowledge, but with social services as well. In 1986 BPPM was rated amongst the top five NGOs in Indonesia by winning WWW (What's Working in the World), following nomination by the UN. ${ }^{33}$ BPPM also has an important role in supervising the quality of the facilitation process, assisting local people with technical and financial support and connecting them with external institutions such as banks, government bodies, and private organisations.

\section{The Rukun Tetangga and Participatory Action Research}

The suspicion they encountered within village government encouraged BPPM to build structural cooperation with 13 heads of Kajen household associations (RT, Rukun Tetangga). ${ }^{34}$ In Javanese villages, RT includes all households in the village, and its members regard their fellows as one big family. Despite the fact that people differ in social rank on the basis of wealth, education and prestige, they are expected to show respect to each other. Adherence to the principle of equality is demanded by the members; all should attend the

31 Martin van Bruinessen, NU: Tradisi, Relasi-relasi Kuasa dan Pencarian Makna Baru (Yogyakarta: LKiS, 1994), pp. 243-244.

32 To gain legal recognition, BPPM PMH was registered at the law office on the $1^{\text {st }}$ of October 1980.

33 Purwo Santoso, "Kiprah Pesantren dalam Transformasi: Catatan dari Maslakul Huda," Pesantren, 4: 4 (1988), pp. 82-83.

$34 \mathrm{RT}$ is the smallest unit in the village structure, which consists of a number of households. The number of RTs varies depending on the size of the village. Each village is headed by kepala desa (the head of village) who establishes a special committee, LKMD (Village Resilience Institution), to plan development programs in the village. Below the headman, the village is divided into a neighborhood, association Rukun Keluarga (RK) or Rukun Warga (RW), which in turn is divided into RT, the smallest units. 
community meetings, take equal part in the projects, and contribute the same amount of money and materials. This constitutes the basic level of community participation, in which equality is demanded. Although RT heads should be respected by all the members, village residents insist that no man has the right to consider himself superior to any other residents by virtue of his senior position. Therefore, it is not surprising that members of community often ignore rank in criticizing the failure of $\mathrm{RT}$ elites to fulfill their obligations in respect to broader social needs.

RT heads usually invite their members to monthly meetings to participate in discussion of important community issues. Even though the RT head offers advice about the issues under consideration, he never uses his authority to force its solution. Usually, project plans are developed in consultation with members of society and consensus building is considered to be extremely important. Some RT heads reject the procedure of holding structured meetings, arguing that they are an unnecessary formality; instead they canvass their neighbors" opinions through informal discussions during the afternoon and evening, when residents generally gather on ward pathways.

It should be noted that despite professed egalitarian principles, the gap between those of high and low rank in the community is frequently obvious in RT meetings, and is borne out in decisions related to the RT village facilities. RT staff members often discuss project execution with the community elites, who are active in community affairs, before presenting the plan to the members to mobilise kerja bakti (community working bees). The RT elites, such as government staff and wealthy people, agree to contribute larger amounts of money. They present the cost of projects to the RT meeting to reach consensus on raising required funds, and to determine the work roster. However, a lack of consensus decreases the residents' support for the project, and in turn leads to failure. This RT situation in Kajen is similar to that in kampung in Yogyakarta. ${ }^{35}$ Guinness also gives examples of projects that have failed due to a lack of support from RT members. ${ }^{36}$

35 Patrick Guinness, Harmony and Hierarchy in A Javanese Kampung (Singapore: Oxford University Press, 1986), pp. 178-181.

36 Ibid., pp. 154-156 
Before the introduction of participatory action research (PAR) and the formation of KSM (self-help group), BPPM utilised the monthly RT meeting to stimulate people's participation. BPPM staff offered participatory development to 13 heads of RT and convinced them of its potential to improve their living conditions. It was recognised that at this stage the role of BPPM staff was pivotal, especially in conducting research to identify village problems. In every RT meeting, BPPM staff asked for time to discuss the negative impact of social and economic problems identified through their own research in the village. They also identified potential solutions that could be put in place to resolve the problems. BPPM staff, for example, explained to the villagers that village advancement was hampered by deficiencies in the local economy, such as the increase in unemployment, limited job opportunities, and difficulty in finding initial capital to fund new enterprise. In addition, many farm labourers could not afford to meet their fundamental needs such as food, health and basic education.

On such occasions, BPPM staff enlisted the kyai to motivate people to participate by giving religious justification to certain development programs. The kyais involvement ensured the development program was in line with Islamic doctrine. For example, when the kyai explained a health program such as the nutritional improvement, he cited the Qur'anic verses and the Prophet traditions related to this topic. ${ }^{37}$ However, unlike in Madura where the kyai was used to promote participatory development on an operational level, in the pesantren Maslakul Huda, the kyai's role was limited to convincing both leaders of the pesantren and members of society about the quality of such development programs. Mahfudz, for example, provided religious justification for development programs through training sessions, seminars and workshops. In this context, the charisma of the kyai was utilised as the entry point to generate acceptance of

\footnotetext{
${ }^{37}$ Kyai Sahal Mahfudh quoted Sura: "Messengers, eat good things and do good deeds: I am well aware of what you do". See, MAS Abdel Haleem, 2005. the Qur'an (Oxford: Oxford University Press, 2005), p. 217. He explained that in this verse God ordered Muslims to eat good, nutritious foods before ordering them to conduct good deeds. He goes on to say that nutrition is important not only to fulfill the physical needs of human beings, but also to fulfill required spiritual activity. Without sufficient nutrition, Muslims will not be healthy and strong; therefore, it hampers them from performing perfect worship. See, MA Sahal Mahfudh, "Pembinaan Gizi dan Kesejahteraan Keluarga (dari Sudut Pranata Agama dan Tokoh Agama)," Paper presented to National Discussion on Gizi (14-19 October 1991), p. 3.
} 
development programs, and was not used to facilitate the process of planning specific development programs with the people.

Changes occurred in 1983, when LP3ES introduced participatory action research into village facilitator training held by BPPM. This training (LTPM) ${ }^{38}$ was undertaken to prepare new facilitators for 13 villages $^{39}$ in Margoyoso sub-district. Unlike the first LTPM held by LP3ES in 1978, this training, which included PAR, lasted for one year, from recruitment to evaluation stages. Moreover, this LTPM was not intended exclusively for senior santri and ustadz from the pesantren; rather, it recruited 28 male and 28 female village youths from 13 villages who had been recommended by formal (village head) and informal (kyai) figures. The expansion of training program was intended to accelerate the implementation of participatory development in all villages in the sub-district of Margoyoso..$^{40}$

Regarding this training, one of the participants, Murthadi, a village farmer, said that the training program he attended six years ago had deeply influenced the way he promoted participatory development in his village. He noted:

The training subjects, like work ethics from an Islamic perspective, managerial and cooperation skills, adult education methodology, learning to listen to other people, and program planning, increased my self-confidence to facilitate and motivate other people. It also helped me adjust to new environments and enhance social sensitivity to other people's needs. So, I am always ready to learn from guests from my village visiting my house. ${ }^{41}$

Having attended one-month's in-class training, the new facilitators undertook four months of action research in their village to get

\footnotetext{
38 BPPM-PMH also held the same training for 30 pesantren in Central, West, East Java and West Kalimantan between 1985 and 1986.

39 These villages are Ngemplak Kidul, Tegalharum, Pangkalan, Pohijo, Purwodadi, Waturoyo, Purworejo, Soneyan, Semerak, Langgen Harjo, Cebolek, Sodomukti and Bulumanis Kidul.

${ }^{40}$ Hadimulyo, “Latihan di Mana-mana," Pesan (November-December 1983), pp. 9-15.

${ }^{41}$ P3M, Laporan Hasil Penelitian untuk Pengembangan Program BPPM Maslakul Huda Kajen Margoyoso Pati (Jakarta: P3M, 1990), p. 35.

43 Russ Dilts (et. al), "Researchers from the Village: An Indonesian Non-Government Ryral Action and Community Development Program," Innotech Journal, 1 (January-June 1999), pp. 35-36.
} 
specific information about village situations. The data included economic and social conditions of villagers, existing communication and influence networks, social and inter-group conflicts, nonfunctioning government programs, farmer difficulties with loan sharks/credit system, family income utilization, land title disputes, perceptions concerning formal education, belief systems, pressure on landless people, labour/and ownership patterns, and attitudes toward development programs. The data were obtained through personal observation, and by holding interviews with informal and formal figures to problematise the village situations. Most importantly, the facilitators also held informal interviews with groups of ordinary people in villages using participatory methods. They also employed adult education, inspired by Freire, that used structured experience (kaji urai). Local people were encouraged to analyse their daily life experiences and to relate them to broader village problems. The following quotation describes how the facilitators build people's awareness, and to encourage them to analyse their situation.

Early morning in the village of Kajen, a young woman wearing a kerudung (veil) sits with a group of illiterate peasant, women. They are drawing squares or circles, the size of which indicates their perception of their own understanding relative to other villagers in terms of landholding, wealth, welfare, education or happiness. The conversation is lively as they dig deeper into their circumstances and their problems. "Why are we unable to send our children to school? Why are some people poor and others rich? Is it because the poor are lazy? Is it fate? What does our religion say about this?' These women from the culture of silence are asked another question by the young woman after they have listed 'important' people in their community, again using graphic representation: 'If the size of this square represents the influence of the opinions of this particular person, draw a square representing the influence of your own opinions in the community...' The session ends with the peasant women asking the young woman personal questions about herself, her family, and her background. The session had begun in this manner, with the young woman inviting questions: 'You know my name, but why do you think I want to talk with you? What reasons do you have for not trusting persons like myself? What are differences between us?' At the end of their meeting, they decide when they will meet again, what they 
will discuss and who else they will invite to join them. In subsequent sessions, folk sayings, Quranic passages, and development slogans will be used as discussion starters... Groups will analyse the meaning and the relevance of the content of these 'messages' in terms of their own life experiences. Using projective techniques with questions such as 'what do your neighbours complain about most?' And by the use of drawings and posters, a picture of social interaction patterns and family activities will be developed and discussed. ${ }^{43}$

The data gathered by the facilitators was systematised and classified in consultation with the staff of BPPM Maslakul Huda, then checked for accuracy through consultation with the villagers. In such discussions, they also proposed problem-solving alternatives, based on the skills and resources of the villagers. This type of research was conducted in 13 villages around Kajen, each with its own problems and assets; therefore, the solutions offered were diverse. In Kajen, for example, the pollution of tapioca waste, health care (building public wells and toilets), and enhancement of the prosperity of workers in the tapioca home industry became major concerns of the village. In contrast, concerns in Sidomukti extended beyond fixing health problems to increasing livestock raising activity, such as beef cattle farming. Proposed alternative solutions to identified problems were then prioritised on a scale from the most urgent to the least urgent, and prepared for presentation at a village seminar.

At the end of fourth month of action research, the facilitators held a village seminar at the village office that was attended by the pamong desa (village officials), the local kyai and the villagers, including those who participated in the research. In this seminar, the facilitators presented their research findings, and the attendees were invited to criticise and offer further suggestions. The seminar was then followed by the action plan, and the formation of KSM to conduct specific development activities.

Interestingly, during the seminar, the village officials often rejected the findings, especially those related to problem identification, because these were related directly to their responsibilities in conducting development programs. For example, a problem identified by the facilitators and the interviewed villagers was annual flooding. Villagers claimed that officials did not take sufficient measures to 'prevent' the flood, and insisted that the harm it caused could be abated by building 
people awareness and mobilising local resources. In reply, the village officials refused to acknowledge that the flood was a problem, arguing that such flooding was a regular event, and the villagers should simply get used to the situation; if flooding occurred, its impact could be overcome. There was a marked difference in the way the recurring flood was viewed by officials and villagers. The officials accepted the flood as part of their life, and as a natural disaster that could not be prevented, but villagers recognised a problem that could be solved.

The implementation of PAR increased the reputation of the pesantren and facilitators among the government officials. The camat (sub-district head) of Margoyoso asked BPPM to train the village heads in the sub-district, noting that "the cadres (village facilitators) seem to be better than the village heads at facilitating and planning community activities". ${ }^{44}$ Moreover, some of the village facilitators trained by the pesantren were promoted to positions within village institutions that channeled society's aspirations, such as the Deliberative Institution (LKMD and LSD). ${ }^{45}$ The government's effort to include the pesantren cadres and other informal leaders in LKMD and LSD was intended to increase grass roots support. The village head fulfils dual roles as implementer of central government policies, and as representative of the people who elect him. A conflict of interest arises when he is directed from above to implement a development program that may contradict with the needs of his constituents, the villagers.

To counter this, the inclusion of village facilitators in such institutions as LKMD and LSD enables them to influence the decision making process that affects village development programs, as shown in action research and village seminars. This situation is very different from the initial stages of participatory development, when the village officials of Kajen and sub-district government of Margoyoso were

\footnotetext{
44 Ibid., p. 41

45 LKMD (Lembaga Ketahanan Masyarakat Desa, Village Resilience Body) was set up by the presidential instruction no. 28/1980 with the specific aim of getting the village community involved in all aspects of planning village development activities. Its function also extends to coordination of all government activities at the village level, and to improve overall government services. The LKMD consists of the village head, village officials and other representatives from the village. See, Colin MacAndrew, "Central Government and Local Development in Indonesia: An Overview," in Colin Mac Andrew (ed.), Central Government and Local Development in Indonesia (Singapore: Oxford University Press. 1986), p. 39.
} 
suspicious of these initiatives. They regarded such programs as Partai Persatuan Pembangunan (PPP, United Development Party) political campaigns intended to win villagers' votes in the general election. In the late 1970s, when participatory development was first promoted, the pesantren and Nahdlatul Ulama (NU) were considered to be affiliated to PPP whereas the village and sub-district heads were government officials, and were affiliated to other political party, Golongan Karya. Furthermore, many PPP activists also claimed that the pesantren Maslakul Huda was co-opted as a political instrument by Golongan Karya to conduct certain development programs in Kajen. It was unusual at that time for religious institutions such as the pesantren to conduct development programs.

\section{The Kelompok Swadaya Masyarakat and Development Programs}

Having being trained in PAR and BPPM, village facilitators did not hold RT meetings; rather, they encouraged the local people to form new social groups, namely, Kelompok Swadaya Masyarakat (KSM, selfhelp group). The formation of KSM in Kajen and in other villages in Margoyoso began after the TPM held a village workshop during the action research process of 1983. The establishment of KSM, which consisted of 20 to 30 people, enabled its members to identify the economic and social problems they faced, analyse their strengths and weaknesses, and determine the most effective solutions to their problems. KSM fostered equal and non-paternalistic relationships among their members, which enabled people to express their own interests and opinions, and ensured that programs were not conducted without awareness of the real issues.

According to a P3M report, around $62 \mathrm{KSM}$ groups were built in cooperation with BPPM Maslakul Huda and P3M. These comprised 2495 members in 1990, not only from the village of Kajen and subdistrict of Margoyoso, but also from three other districts in central Java. ${ }^{46}$ Most of the KSM groups were located in agricultural regions, and most of their members were educated to either primary or secondary school level. Their income levels were typically lowranging from Rp. 30,000 to Rp. 90,000 per month.

46 P3M, Laporan Hasil Penelitian, p. 10. 
The evaluation held six months after program implementation revealed that awareness building and people participation in the KSM became important aspects of the groups' existence. Twenty-three out of sixty two existing KSM groups coordinated by BPPM were inactive. The groups were not well prepared to become self-help groups in the sense that their formation was not based on a proper assessment of the real problems, potentials, opportunities and challenges surrounding them. In other words, awareness building was neglected in the formation of groups. They were spontaneously formed to obtain funds from BPPM, which were basically intended to assist in developing group potential. As a result, the solidarity among the members was fragile, and the groups became inactive when the fund was exhausted. The members were not equipped with technical skills to manage specific enterprises, and as a result, the type of group enterprise pursued was determined by dominant group members who possessed certain skills. This hampered participation for all members. In contrast, for active KSM groups, the most important goal was building group capacity, rather than relying on loans. These groups analysed their situation and gauged their potential through needs assessments conducted with the support of village facilitators, and then they sought start-up capital for a new enterprise.

To fulfil the capital needs, the KSM conducted income-generating activities such as group savings and loans, or UBSP (Usaha Bersama Simpan Pinjam). The simpan pinjam is a common activity of KSM in which the members commit themselves to depositing a certain amount of money each month, which can be lent out to any one of them at a moderate interest rate. Subsequent profit on loans is then divided among members annually. The simpan pinjam helped free members from the lack of capital which could lead to their dependency on moneylenders, and to the practice of gadai (pawning). In savings and loans, there are three kinds of savings, with the amount of money determined by the member agreement. The first is simpanan pokok (main saving), each member contributing the same amount of money, usually between Rp. 5,000 and Rp. 10,000, which can be paid in instalments over several months. The second type is simpanan wajib (obligatory saving), paid by the members weekly. The third type of saving is simpanan manasuka or sukarela (private saving), with the amount dependent on the members' financial capability. The amount of money that can be borrowed by the members is determined by the 
appropriateness of the enterprise conducted by member or group. If the enterprise is profitable and needs lots of capital, the members are eligible for big loans. When this program commenced in 1983, a member usually could borrow up to Rp. 25,000. Increases in group savings stimulated the motivation of members to increase production, or to create new enterprises.

In this saving and loan group, late payments are always discussed by the members during their monthly meeting. The group organisers and some members try to find the cause of the lateness, and remind the members of their payments. If the cause of inability to repay a loan is misfortune, the members will contribute tenggang renteng ${ }^{47}$ to cover the outstanding debt. Until complete repayment has been made, other members are not able to take a loan because the outstanding sum is unavailable for loan. When the assisted member is finally able to repay the debt, the amount deposited is returned to the members. This tenggang renteng system creates cooperation and mutual assistance within the group. It also provides a forum in which all members can contribute something towards the welfare of this group; hence, to safeguard group capital.

For established KSM groups--the groups that undertake certain enterprises--BPPM provide certain loans (revolving funds) to inject additional capital into their existing enterprises. In other words, the KSM group must have its own capital before receiving funds from BPPM. In this context, building group capacity has become the highest priority, and the external loans are treated as additional support for the group's enterprises. The sum lent to the group is up to five times the value of the available group capital. This stimulates members to increase the group's savings. Furthermore, BPPM enhances the group's abilities by offering consultation, training, and supervision. BPPM also helps establish certain connections between established KSM and institutions such as banks, government departments, and business companies, in order to build further cooperation and to get wider market access.

This loan system has been utilised to develop the krupuk industry in Kajen. In this major home industry, tapioca flour is used for making

\footnotetext{
47 This refers to collective contributions made to repay the member's loan due to his/her inability to repay according to the schedule. Failure of one member to make timely payments causes delays for subsequent borrowers.
} 
tapioca crisps (krupuk). The rise of such an industry is encouraged by the availability of raw materials, that is, tapioca flour, which is easily sourced from the neighbouring village. Raw material is purchased from Ngemplak Kidul village, then processed with the assistance of family members, and the krupuk is finally sold in the local market of Kajen, and in public gatherings such as public pengajian and thripath meetings. It is also sold to brokers, who resell it in markets outside Kajen. ${ }^{48}$ However, due to the small amount of capital they own, many krupuk producers cannot increase their production and their profits.

BPPM also provides loans of Rp. 10,000 for every household, with the requirement that they must pay administration costs of Rp. 500. So far BPPM has provided loans of Rp. 650,000 distributed among 65 households. From the krupuk industry, the villagers could potentially realise profits of Rp. 750 to Rp. 1500 per day. The villagers also contribute the amount of their tabungan sukarela, which within three years reached Rp. 750, 000. It is worthwhile to add this amount to their loan to increase the production capacity of the krupuk industry. Apart from providing loans to the krupuk industry, BPPM also supports the industry with management skills, ranging from processing to marketing. To assist with this, BPPM invited a pesantren alumnus who successfully managed a krupuk industry in Sidoarjo ${ }^{49}$ to give the training. With the improvement of product quality, and wider access to the market, this effort increased the development of the krupuk industry in Kajen. Some home industries even managed to employ 10 to 15 people.

Figure 2: The Relationship of BPPM, Village Facilitators and KSM

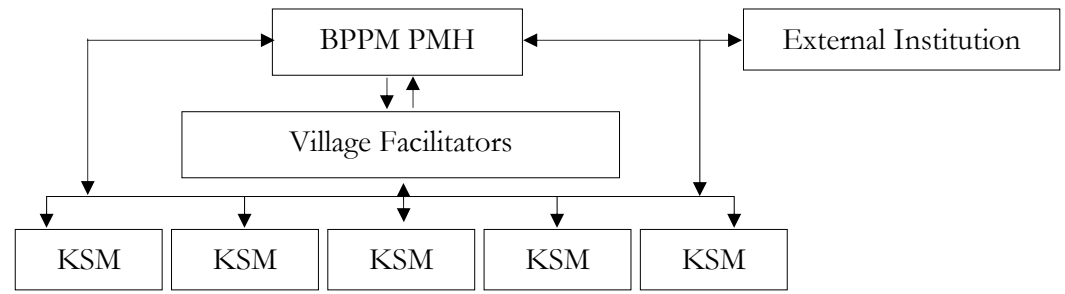

Apart from savings and loans for the krupuk industry, there were a number of development programs conducted by BPPM-PMH during their cooperation with LP3ES, P3M and external institutions such as

\footnotetext{
48 Mufid, Tangklukan, Abangan dan Tarekat.

${ }^{49}$ Sidoarjo is the largest krupuk industry centre in East Java, and possibly Indonesia.
} 
government departments and banks. Another example of an important development program related to beef cattle (ternak sapi). In this program, local people participated based on their identified problems, potentials and available village resources. The roles of facilitator and BPPM were important in building awareness and providing support in the form of technical skills, and financial assistance through additional loans.

\section{Figure 3: Examples of Development Program Conducted by BPPM Maslakul Huda in Cooperation with LP3ES and P3M}

\begin{tabular}{|c|c|}
\hline Activity & Year \\
\hline Beef cattle farm & 1985-now \\
\hline $\begin{array}{l}\text { Skills training (embroidery, animal husbandry such } \\
\text { as fish and prawns) }\end{array}$ & 1983,1989 \\
\hline $\begin{array}{l}\text { Savings and loans, revolving fund for improving } \\
\text { enterprises }\end{array}$ & 1979-now \\
\hline $\begin{array}{l}\text { Mediating peanut industry and tapioca home } \\
\text { industry in supplying tapioca flour }\end{array}$ & $1979-1983$ \\
\hline $\begin{array}{l}\text { Leadership and management training for KSM } \\
\text { leaders }\end{array}$ & 1989 \\
\hline Water supply & 1987 \\
\hline $\begin{array}{l}\text { Appropriate technology (water pumps, rope pumps, } \\
\text { hydrant pumps, Ferro cement, energy saving stoves) }\end{array}$ & 1980 \\
\hline Animal husbandry training (fish and prawns) & 1989 \\
\hline $\begin{array}{l}\text { Community health program (health fund and health } \\
\text { cadres, tapioca waste drainage construction) }\end{array}$ & 1979-1987 \\
\hline Redemption of pawned agricultural land & 1983-1985 \\
\hline $\begin{array}{l}\text { Village facilitator training for } 30 \text { pesantren in East, } \\
\text { Central and West Java }\end{array}$ & 1983-1986 \\
\hline Agricultural training and farmers cooperative & 1985 \\
\hline
\end{tabular}

The initial livestock enterprise was held by KSM in Sidomukti village, and was then developed in other villages such as Ngemplak. This enterprise was developed in recognition of the fact that many villagers in Sidomukti have livestock for their own livelihoods, unrelated to their work in the agricultural sector. ${ }^{50}$ Their livestock are extremely important to the villagers because of the vulnerability of their agricultural crop to failure, through insect attacks, or increased

50 LP3ES and BPPM PMH, Laporan Latihan Tenaga Pengembangan Masyarakat (LTPM) Untuk. 13 Desa Kecamatan Margoyoso Kabupaten Pati II (Putri) (Kajen: BPPM PMH, 1983), p. 28. 
fertiliser prices. In agricultural regions such as Sidomukti, there is very strong support for developing such enterprises, because pasture to feed livestock is readily available. Moreover, the tapioca waste (cassava peel, and waste), produced by home-industry in Kajen and Ngemplak Kidul, can be utilised as organic food for the livestock after processing. Kajen and Ngemplak Kidul are famous centres for the production of tapioca flour, which is the basic ingredient of the tapioca crisps produced in the villagers' home industry. However, the waste treatment is not properly managed, and has resulted in a bad smell pervading the surrounding environment. In Ngemplak, Kajen's neighbouring village, there are many tapioca flour home-industries that produce more than five tonnes per day. These industries can employ at least 2,000 villagers from Ngemplak village and surrounding villages.

The Sidomukti KSM had 20 members who maintain beef cattle. In late 1985, this KSM had initial capital from the group savings and loan program of around Rp. 1 million. BPPM-PMH then provided an additional loan of Rp1 million to the KSM. This sum was designated to buy four cattle, which were distributed to the chosen members based on the group agreement, and were put in the breeders' ownership. The maintenance process took between four and five months, and the costs related to the maintenance were borne by the maintainers. After four months of maintenance, the cattle were ready to sell at around Rp. 2.8 million. This meant that the group realised a profit of Rp. 800, 000 for four cattle. Each owner then received Rp. 200,000 and the remaining sum of Rp. 400,000 was returned to the KSM savings, and used for buying new cattle to be bred by other members Therefore, within one year the KSM was able to increase their cattle numbers to seven.

By 1988, the beef cattle program had developed, and received significant financial and technical support-not only from BPPMPMH, but also from government institutions such as the Department of Agriculture of Pati District. In managing such development, the KSM worked in a more organised and efficient way. In discussions with BPPM-PMH about their plan, they reached an agreement to manage the implementation of the program. They not only provided some facilities including pens, food processing, and cattle but also formed the committee coordinating the program. With the financial support from BPPM, P3M and Central Java government, the KSM bought 20 cattle, which were put in a 400 metre square pen was 
located in the outskirts of Sidomukti village. The pen was built by the members of KSM on land they rented from local villagers. To enhance the quality of breeding process, the KSM did not rely on the grass and other agricultural products available in the village, but utilised the tapioca waste produced in surrounding villages. To support the use of this waste BPPM-PMH, in cooperation with the Department of Agriculture of Pati District, provided the KSM with a livestock food processor that was obtained from the Institute of Technology of Bandung (ITB). ${ }^{51}$ In addition, the KSM members also received training on the use of machine, and the process of making the livestock food. The use of tapioca waste was intended to decrease the problem of waste pollution besetting Kajen and surrounding villages, and to enhance the quality of the cattle. Within four months the cattle were ready to sell. The benefit of cattle selling was shared among three parties: BPPM-PMH (40\%), KSM saving $(10 \%)$, and the maintainers $(50 \%)$. In the first stage of the maintenance process, there were 9 members of the KSM who were responsible for maintaining the cattle, and who received the benefit. Having realised profits from selling the cattle within 4 months, the rest of the KSM members have the same opportunity to manage the livestock, depending on their agreement. ${ }^{52}$

\section{Participatory Development and Social Position of the Pesantren Maslakul Huda}

The creation of KSM, as advocated by participatory development in the pesantren Maslakul Huda, benefits both local people and the pesantren. The KSM groups are utilised by the villagers as a means of building awareness, identifying problems and potentials and mobilising available resources for the sake of self reliance. It is also apparent that the pesantren enjoys great advantages from the development activities they conduct. Through its cooperation with a number of KSM in

51 ITB was one institution which built cooperation with LP3ES in the pesantren program in early 1980s by offering appropriate technology for rural areas. However, this appropriate technology program was not entirely successful because it was topdown and the implementation often did not consider its suitability to local people' needs and local cultural dimension. See, Amri Marzali, Antropologi dan Pembangunan Indonesia (Jakarta: Prenada Media, 2005)

52 Gufron, "Peran Pesantren Maslakul Huda dalam Pengembangan Masyarakat Bidang Peternakan di Desa Sidomukti Kecamatan Margoyoso Kabupaten Pati Jawa Tengah," (Unpublsihed Bachelor Thesis. Yogyakarta, Fakultas Ushuluddin, Universitas Islam Negeri Yogyakarta, 2006), p. 42. 
Kajen and other villages, the pesantren usually receives between $20 \%$ and $40 \%$ of the profit generated by certain programs. The remaining $60 \%$ to $80 \%$ is given back to the members of the KSM. The existence of the KSM attracts external institutions to build cooperative relationships, and provides the pesantren with considerable financial benefits. The profits accumulated as a result of such relationships have enabled the pesantren Maslakul Huda to establish financial institutions such as BPR Artha Huda Abadi (People Credit Bank), 53 Shari Saving and Loan Bank, as well as cooperatives, public telephones and a workshop. ${ }^{54}$

There is a range of underlying reasons behind the establishment of such institutions. First, as an educational institution, the pesantren should be able to provide considerable sums to finance its own operational costs, including construction of educational facilities. In the earliest days of the pesantren many kyais were landowners in addition to being religious leaders, and the pesantren was thus able to finance itself. In addition, the villagers and the santri's parents contributed cash or other donations to support the operation of the pesantren. Nowadays, with decreased santri enrolment, and cessation of kyai land ownership (particularly in Kajen, which lacks agricultural land), a lack of financial resources has resulted in difficulties in the pesantren running a sustainable educational mission. Secondly, the establishment of profitable institutions was also intended to eradicate the financial dependency of the pesantren and the KSM on external funding sources, such as NGOs and the government, in conducting development programs. Before the establishment of BPR, the amount of revolving funds distributed to the KSM was limited, and was

${ }^{53}$ BPR initially was founded by BPPM in 1995 with initial capital of Rp. 150,000,000,-. Share ownership was divided among three parties: BPPM (29\%), LP3ES (51\%), and pesantren families and graduates $(20 \%)$. However, five years later BPPM changed the distribution of share ownership to BPPM (51\%), LP3ES (29\%), and pesantren families and pesantren colleagues (20\%), arguing that BPPM and the pesantren proposed the establishment of BPR and subsequently managed it, whereas LP3ES only provided initial capital.

54 The workshop enterprise resulted from utilisation of equipment provided by the Department of Religious Affairs in 1973. The workshop initially was intended to be a laboratory in which santri could develop workshop skills. In later development, this facility was utilised by the pesantren for business purposes, employing KSM who were interested in the field. The enterprise attracts profit sharing both for the pesantren and KSM. See, Alwie, Pesantren Maslakul Huda, p. 185. 
derived partly from external funding agencies; therefore it limited program acceleration. Moreover, the government contribution was usually followed by political consequences, such as influencing the pesantren and the kyai to support government programs, and at worst, supporting the status quo. Likewise, NGOs had their own agendas in giving financial support.

Apart from these reasons behind the establishment of profitable institutions owned by the pesantren, it is clear that the pesantren was strategic in building external cooperation (with organisations such as LP3ES and P3M) that benefited its institution. With the establishment of BPR owned by the pesantren, financial assistance could be offered to the KSM which were under its guidance. The more money KSM borrowed towards the costs of running certain programs, the more wealth the pesantren could accumulate through profit sharing. When the BPPM facilitated certain development activities and equipped the KSM with technical skills to ensure the success of the programs, it also ensured a smooth flow of cash from the KSM to the pesantren. Therefore, the BPPM was a kind of bank with additional facilitation functions. It effectively allowed a handing over of KSM financial dependency from NGOs, donors and outside financial institutions, to the pesantren Maslakul Huda. It has also resulted in a shift in the status of the kyai-in the past they were economic and social elites by virtue of their religious knowledge and land ownership. Today, although this status has not diminished, the kyai and the pesantren Maslakul Huda are recognised as economic and social elites on the basis of financial resources, rather than landowning.

\section{Conclusion}

Participatory development in the pesantren Maslakul Huda has led to the creation of genuine participation among local people. This is especially palpable after the introduction of participatory action research in facilitator training held by the pesantren and LP3ES. This training recruits male and female youth representatives to become facilitators in their own village, and is intended not only to expand the dissemination of participatory development, but also to ensure that the participatory process is conducted by local people. The creation of KSM (self-help groups) as new people forums in the village enables them to identify their own problems, potentials, and to propose alternative solutions. Furthermore, unlike the pengajian in which the kyai's authority influences the forum, in KSM the kyai is excluded. This 
means the members have a more equal relationship, and avoid being pressured by the kyai's influence in the decision making process. The kyais role in the pesantren Maslakul Huda is limited to justifying participatory development and the suitability of certain development programs through Islamic doctrine. The facilitation process is in the hands of BPPM staff and village facilitators who are not kyai or ustad\%:

It is undeniable that participatory development has assisted the pesantren Maslakul Huda in establishing its role in social services in a more organised way, without uprooting it from its mission. This is achieved by giving Islamic justification for participatory development, labelling it as ibadat sosial (social worship), and describing it as the fulfilment of Muslim leaders' obligations to their constituents. Furthermore, the intensive cooperation between the pesantren, KSM and NGOs enables the pesantren to enjoy financial benefits. These benefits extend to establishment of financial institutions, such as banks, to help avoid financial dependency on external funding sources. Such institutions enable the pesantren to become self-financing, and allow them to offer loans to the KSM. By offering loans to the KSM, the pesantren can accumulate greater financial resources, and shift KSM dependency on external funding, from NGOs on to themselves. Therefore, while participatory development offers a chance to local people to have their own voice, and develop the ability to negotiate with local government (transformative at the local level between local people and local government), it also gives the pesantren the means to sustain its domination over the surrounding society. []

\section{Bibliography}

\section{Books and Articles}

Alwie, Alfoe Ni'am. Pesantren Maslakul Huda: Membentuk Insan Mandiri. Yogyakarta: Wisma KMF Papringan, 2004.

Budiman, Arief. "The Emergence of the Bureaucratic Capitalist State in Indonesia." in Tech Ghee Lim (ed.). Reflections on Development in Southeast Asia. Singapore: Institute of Southeast Asian Studies, 1988. pp. 110-129.

Dilts, Russ (et. al). "Researchers from the Village: An Indonesian NonGovernment Rural Action and Community Development Program.” Innotech Journal. 1 (January-June 1999): pp. 34-42. 
Dirdjosanjoto, Pradjarta. Memelihara Umat: Kiai Pesantren and Kiai Langgar. Yogyakarta: LKiS, 1999.

Faiqoh. Nyai: Agen Perubahan di Pesantren. Jakarta: Kucica, 2003.

Fakih, Mansour. "Pengembangan Masyarakat di Pesantren: Hambatan dan Permasalahan." in Manfred Oepen and Wolfgang Karcher (eds). The Impact of Pesantren in Education and Community Development in Indonesia. Jakarta: P3M, 1985. pp. 148-160.

Geertz, Clifford. "The Javanese Kijaji: The Changing Role of A Cultural Broker." Comparative Studies in Society and History. 2: 2 (1960): pp. 228-249.

Gufron. "Peran Pesantren Maslakul Huda dalam Pengembangan Masyarakat Bidang Peternakan di Desa Sidomukti Kecamatan Margoyoso Kabupaten Pati Jawa Tengah." Unpublished Bachelor Thesis, Yogyakarta, Fakultas Ushuluddin, Universitas Islam Negeri Yogyakarta, 2006.

Guinness, Patrick. Harmony and Hierarchy in A Javanese Kampung. Singapore: Oxford University Press, 1986.

Hadimulyo. "Latihan di Mana-Mana." Pesan (November-December 1983): pp. 9-15.

Haleem, MAS Abdel. The Qur'an. Oxford: Oxford University Press, 2005.

Hasan, M Nashihin. "Karakter dan Fungsi Pesantren." in Manfred Oepen and Wolfgang Karcher (eds). The Impact of Pesantren in Education and Community Development in Indonesia. Jakarta: P3M, 1985. pp. 108-109.

Horikoshi, Hiroko. "A Traditional Leader in a Time of Change." Unpublished Ph.D Thesis, Urbana: University of Illinois at Urbana-Champaign, 1976.

Jones, Sidney. "The Javanese Pesantren: Between Elite and Peasantry." in Reshaping Local Worlds: Formal Education and Cultural Change in Rural South East Asia. New Haven, Conn: Yale Centre for International and Area Studies, 1996. pp. 19-41.

Kartodirdjo, Sartono. Protest Movement in Rural Java: A Study of Agrarian Unrest in the Nineteenth and Early Twentieth Centuries. Singapore: Oxford University Press, 1973. 
LP3ES and BPPM PMH. Laporan Latihan Tenaga Pengembangan Masyarakat(LTPM) Untuk 13 Desa Kecamatan Margoyoso Kabupaten Pati II (Putri). Kajen: BPPM PMH, 1983.

MacAndrew, Colin. "Central Government and Local Development in Indonesia: An Overview." in Colin Mac Andrew (ed.). Central Government and Local Development in Indonesia. Singapore: Oxford University Press, (1986): pp. 6-19.

Mahfudh, MA Sahal. "Pembinaan Gizi dan Kesejahteraan Keluarga (Dari Sudut Pranata Agama dan Tokoh Agama)." Paper presented to National Discussion on Gizi. 14-19 Oktober 1991. --------. Nuansa Fikih Sosial. Yogyakarta: LkiS, 1994.

Marzali, Amri. Antropologi dan Pembangunan Indonesia. Jakarta: Prenada Media, 2005.

Mansurnoor, Iik Arifin. Islam in an Indonesian World: Ulama of Madura. Yogyakarta: Gadjah Mada University Press, 1990.

Mudatsir, Arief. "Kajen Desa Pesantren." in M. Dawam Rahardjo (ed.). Pergulatan Dunia Pesantren: Membangun dari Bawah. Jakarta: P3M, 1985.

Mufid, Ahmad Syafi'i. Tangklukan, Abangan dan Tarekat: Kebangkitan Agama di Jawa. Jakarta: Yayasan Obor Indonesia, 2006.

P3M. Laporan Hasil Penelitian untuk Pengembangan Program BPPM Maslakul Huda Kajen Margoyoso Pati. Jakarta: P3M, 1990.

Rahardjo, M. Dawam. "The Kyai, the Pesantren and the Village: A Preliminary Sketch.” Prisma: The Indonesian Indicator, vol. 1, no. 1 (1975): pp. 32-43.

Santoso, Purwo. "Kiprah Pesantren dalam Transformasi: Catatan dari Maslakul Huda". Pesantren. 4: 4(1988): pp. 80-87.

-------. "Political Challenges to Sustainable Development in Indonesia." Unpublished MA Thesis, Ann Arbour, 1992.

van Bruinessen, Martin. NU: Tradisi, Relasi-Relasi Kuasa dan Pencarian Makna Baru. Yogyakarta: LKiS, 1994.

--------. Kitab Kuning,Pesantren dan Tarikat: Tradisi-Tradisi Islam di Indonesia. Bandung: Mizan, 1995.

World Bank. World Development Report 1991: Poverty. Oxford: Oxford University Press, 1991.

Yunus, Mahmud. Sejarah Pendidikan Islam di Indonesia. Yakarta: Mutiara, 1979. 